\title{
PENEMUAN HUKUM OLEH HAKIM MAHKAMAH \\ AGUNG DALAM PUTUSAN PERKARAKEWARISAN ISLAM DI INDONESIA PADA TAHUN 1995-2014
}

\section{Shobirin \\ Dosen Sekolah Tinggi Agama Islam Negeri Kudus \\ Email : shobir102@gmail.com}

\begin{abstract}
Abstrac
This article discusses about jurisprudence of the High Court concerning the case of inheritance among Muslim society in Indonesia. There three main issues examined: (1) law finding by Supreme Court Justice concerning the case of inheritance, (2) the decision of the Supreme Court in the case of inheritance from the perspective of Istinbath al-hukm, and (3) the degree of progressivity of the Judge's decision toward the issue of justice in Indonesia. This is a library research in which data are collected from documents and other available resources. The method of analysis is normative qualitative.
\end{abstract}

Keywords: law finding, Supreme Court Justice, Islamic inheritance

\section{Pendahuluan}

Tradisi hukum kewarisan Islam di Indonesia tidak tunggal, melainkan beragam, yaitu ada tradisi hukum kewarisan yang bersumberkan dari hukum Islam, hukum adat dan perdata/BW. Perpaduan unsur-unsur tradisi hukum tersebut, diharapakan mampu mengakomodasi rasa keadilan semua lapisan masyarakat dan dinamika perkembangan masyarakat. Dengan demikian, putusan hakim Mahkamah Agung dalam perkara kewarisan Islam sebagai Law in Action dianggap tepat apabala melihat pola-pola dan fakta dinamika tradisi hukum tersebut, yaitu memadukan hukum Islam, hukum adat dan Perdata, serta mengakomodir peran dan dimensi sosial.

Berangkat dari fakta tersebut, maka penemuan hukum oleh hakim merupakan bagian penting dalam penerapan hukum di Indonesia, karena hakim sebagai penegak hukum dan keadilan wajib menggali, mengikuti dan memahami nilai-nilai hukum yang hidup di masyarakat. Masyarakat masih banyak yang mengenal hukum tidak tertulis, sedangkan hakim merupakan perumus dan 
penggali nilai-nilai hukum yang hidup dalam masyarakat. Maka hakim diharapkan dapat membuat putusan yang sesuai dengan aspirasi keadilan masyarakat. Hal ini, yang menjadi inti makna penemuan hukum dalam memecahkan masalah-masalah hukum konkrit yang ada di masyarakat.

Suatu negara yang berdasarkan hukum (rechtstaats), kekuasaan kehakiman merupakan badan yang sangat menentukan isi dan kekuatan kaidah-kaidah hukum yang berlaku dalam negara. Kekuasaan kehakiman ${ }^{1}$ diwujudkan dalam tindakan pemeriksaan, penilaian dan penetapan nilai perilaku manusia tertentu serta menentukan nilai situasi konkret dan menyelesaikan persoalan atau konflik yang ditimbulkan secara imparsial berdasarkan hukum sebagai patokan objektif (Rasjidi dan Ira, 2004: 93).

Tugas pokok hakim adalah memberi keputusan dalam setiap perkara atau konflik yang diajukankan kepadanya, menetapkan halhal seperti hubungan hukum, nilai hukum dari perilaku, serta

${ }^{1}$ Pasal 24 ayat (1) Undang-Undang Dasar 1945 menyatakan bahwa : "Kekuasaan kehakiman merupakan kekuasaan yang merdeka untuk menyelenggarakan peradilan guna menegakkan hukum dan keadilan". Ketentuan tersebut merupakan dasar dari adanya suatu peradilan yang mandiri, netral dan tidak memihak, untuk menyelenggarakan suatu peradilan yang bebas dari campur tangan kekuasaan negara lainnya. Dalam makna yang lebih luas, ketentuan tersebut memberikan implikasi bahwa peradilan sebagai lembaga yudikatif, yang menyelenggarakan kekuasaan kehakiman, tidak dapat dan tidak diperbolehkan untuk dicampuri oleh kekuasaan negara lainnya, baik lembaga eksekutif, yaitu Presiden beserta jajaran di bawahnya, maupun lembaga legislatif, yaitu Dewan Perwakilan Rakyat.

Selanjutnya dalam ayat (2) Pasal 24 Undang-Undang Dasar 1945, dijelaskan bahwa, pelaksanaan dari penyelenggaraan kekuasaan kehakiman dilakukan oleh sebuah Mahkamah Agung dan badan peradilan yang berada di bawahnya, yaitu dalam peradilan umum, peradilan agama, peradilan militer, dan peradilan tata usaha negara serta oleh sebuah Mahkamah Konstitusi.

Lebih lanjut ketentuan tersebut dijabarkan dalam Pasal 18 Undang-Undang Nomor 48 Tahun 2009 tentang Kekuasaan Kehakiman, yang menyatakan bahwa: "Kekuasaan kehakiman dilakukan oleh sebuah Mahkamah Agung dan badan peradilan yang berada dibawahnya dalam lingkungan peradilan umum, peradilan agama, peradilan militer, dan peradilan tata usaha negara dan oleh sebuah Mahkamah Konstitusi”.

Yudisia, Vol. 9, No. 1, Jan-Jun 2018 
kedudukan hukum pihak-pihak yang terlibat dalam suatu perkara, dalam menyelesaikan perselisihan atau konflik secara imparsial berdasarkan hukum yang berlaku, hakim harus selalu mandiri dan bebas dari pengaruh pihak manapun, terutama dalam mengambil suatu keputusan (Rasjidi dan Ira, 2004: 93-94). Hakim adalah pejabat peradilan negara yang diberi wewenang oleh undangundang untuk mengadili suatu perkara yang diajuan kepadanya. ${ }^{2}$ Adapun pengertian dari mengadili itu adalah serangkaian tindakan hakim untuk menerima, memeriksa dan memutus suatu perkara berdasarkan asas bebas, jujur, dan tidak memihak di sidang pengadilan.3

Menurut Rudi Suparmono putusan hakim akan terasa begitu dihargai dan mempunyai nilai kewibawaan, jika putusan tersebut dapat merefleksikan rasa keadilan hukum masyarakat dan juga merupakan sarana bagi masyarakat pencari keadilan untuk mendapatkan kebenaran dan keadilan. Sebelum hakim memutus suatu perkara, ia harus menanyakan kepada hati nuraninya sendiri, apakah putusan ini nantinya akan adil dan bermanfaat (kemașlahat-an) bagi manusia ataukah sebaliknya, akan lebih banyak membawa kepada ke-maḍarat-an, (2006:50) maka seorang hakim di samping mempunyai otak yang cerdas juga harus memiliki hati nurani yang bersih.

Secara umum, tugas dan kewenangan seorang hakim adalah untuk menegakkan kebenaran dan keadilan di masyarakat, dengan berpedoman pada hukum, undang-undang, dan nilai-nilai keadilan yang hidup dalam masyarakat. Dengan demikian, hakim mengemban amanah yang berat, yaitu hakim harus mampu menerapkan peraturan perundang-undangan secara benar dan adil,

${ }^{2}$ Menurut Pasal 1 butir (8) Kitab Undang-Undang Hukum Acara Pidana (KUHAP) : "Hakim adalah pejabat peradilan negara yang diberi wewenang oleh undang-undang untuk mengadili".

${ }^{3}$ Pengertian mengadili sebagaimana terdapat dalam Pasal 1 butir (9) KUHAP adalah : "serangkaian tindakan hakim untuk menerima, memeriksa, dan memutus perkara pidana berdasarkan asas bebas, jujur, dan tidak memihak di sidang pengadilan". 
apabila penerapan peraturan perundang-undangan akan menimbulkan ketidakadilan, maka hakim wajib berpihak pada keadilan (moral justice) dan mengenyampingkan hukum atau peraturan perundang-undangan (legal justice). Hukum yang baik adalah hukum yang sesuai dengan hukum yang hidup dalam masyarakat (the living law) yang tentunya sesuai pula atau merupakan pencerminan dari nilai-nilai yang berlaku dalam masyarakat (social justice) (Manan, 2000:263). Keadilan yang dimaksud di sini, bukanlah keadilan yang bersifat formil, tetapi keadilan yang bersifat materiil atau substantif yang sesuai dengan hati nurani hakim.

Pada kenyataannya pembuat undang-undang hanya menetapkan peraturan umum saja, pertimbangan tentang hal-hal konkret diserahkan kepada hakim. Karena pembuat undang-undang selalu tertinggal oleh kejadian-kejadian sosial (baru) maka hakim harus menambah undang-undang untuk menjawab permasalahan baru (Utrecht, 1983:216). Hakim sebagai pemegang kendali dan penentu hukum di depan persidangan, dapat memberikan sentuhan human pada hukum dan peraturan perundang-undangan, sehingga akan tetap digunakan dalam kerangka penegakan hukum yang berjiwa kemanusiaan.

Kenyataan di lapangan, ketentuan undang-undang selalu berlaku umum dan bersifat abstrak, tidak dapat diterapkan begitu saja secara langsung pada peristiwa konkret, oleh karena itu ketentuan undang-undang harus diberi arti, dijelaskan atau ditafsirkan dan disesuaikan dengan peristiwanya untuk diterapkan pada peristiwanya itu. Peristiwa hukumnya harus dicari lebih dahulu dari peristiwa konkretnya, kemudian undang-undangnya ditafsirkan untuk dapat diterapkan

Secara umum, undang-undang dibuat oleh pembentuk undang-undang untuk melindungi kepentingan manusia, sehingga harus dilaksanakan dan ditegakkan. Namun, kegiatan dalam kehidupan manusia itu sangat luas, tidak terhitung jumlah dan jenisnya, sehingga tidak mungkin tercakup dalam suatu peraturan perundang-undangan secara tuntas dan jelas. Manusia sebagai makhluk ciptaan Tuhan mempunyai kemampuan terbatas, sehingga undang-undang yang dibuatnya, tidaklah lengkap untuk mencakup keseluruhan kegiatan kehidupan manusia, oleh karena itu tidak ada 
undang-undang yang sudah lengkap atau jelas secara sempurna (Mertokusomo, 2007:37).

Sementara undang-undang harus diketahui oleh umum, tersebar luas, dan harus jelas. Kejelasan suatu undang-undang sangatlah penting, dan oleh karena itu setiap undang-undang selalu dilengkapi dengan penjelasan. Akan tetapi sekalipun nama dan maksudnya sebagai penjelas, namun seringkali terjadi, penjelasan tersebut tidak juga memberi kejelasan, karena hanya dinyatakan "cukup jelas", padahal teks undang-undangnya tidak jelas dan masih memerlukan penjelasan (Mertokusomo dan Pitlo, 1993:12).

Hakim dalam memeriksa, mengadili, dan memutuskan suatu perkara yang dihadapkan kepadanya, pertama-tama harus menggunakan hukum tertulis terlebih dahulu, yaitu peraturan perundang-undangan, tetapi kalau peraturan perundang-undangan tersebut ternyata tidak cukup atau tidak tepat dengan permasalahan dalam suatu perkara, maka barulah hakim akan mencari dan menemukan sendiri hukumnya dari sumber-sumber hukum yang lain seperti yurisprudensi, doktrin, traktat, kebiasaan atau hukum tidak tertulis. Pasal 10 ayat (1) Undang-Undang Nomor 48 Tahun 2009 tentang Kekuasaan Kehakiman menentukan bahwa : "Pengadilan dilarang menolak untuk memeriksa, mengadili, dan memutus suatu perkara yang diajukan dengan dalih bahwa hukum tidak ada atau kurang jelas, melainkan wajib untuk memeriksa dan mengadilinya".

Ketentuan pasal tersebut memberikan makna kepada hakim sebagai organ utama dalam suatu pengadilan dan sebagai pelaksana kekuasaan kehakiman, untuk menerima, memeriksa, mengadili suatu perkara dan selanjutnya menjatuhkan putusan, sehingga dengan demikian waijb hukumnya bagi hakim untuk menemukan hukumnya dalam suatu perkara meskipun ketentuan hukumnya tidak jelas ataupun kurang jelas. Permasalahan tersebut, dijelaskan dalam Pasal 5 ayat (1) Undang-Undang Nomor 48 Tahun 2009, menentukan bahwa :"Hakim dan hakim konstitusi wajib menggali, mengikuti, dan memahami nilai-nilai hukum dan rasa keadilan yang hidup dalam masyarakat".

Kata "menggali" tersebut, dapat diasumsikan bahwa sebenarnya hukumnya itu sudah ada, tetapi masih tersembunyi, sehingga untuk menemukannya hakim harus menggali nilai-nilai 
hukum yang hidup dalam masyarakat, kemudian mengikuti dan memahami, agar putusannya itu sesuai dengan rasa keadilan yang hidup dalam masyarakat.

Secara sosiologis praktik penerapan hukum kewarisan Islam, di tengah-tengah masyarakat Islam Indonesia terus berkembang, karena adanya perkembangan masyarakat, ditandai dengan banyaknya kasus-kasus baru tentang kewarisan Islam yang masuk ke Mahkamah Agung yang harus diputus, sesuai dengan kewenangan hakim Agung Mahkamah Agung yang dimiliki.

Keputusan hakim (jurisprudensi) sebagai salah satu sumber hukum formal yang berlaku juga dalam sistem hukum di Indonesia, sudah barang tentu banyak aspeknya yang dapat diteliti guna mendapatkan manfaat dalam pembangunan hukum. Salah satu aspek yang dapat diteliti adalah bila terjadi sengketa antara suatu yurisprudensi dengan hukum yang diatur dalam peraturan perundang-undangan.

Sangat dimungkinkan terjadi sengketa antara suatu yurisprudensi dengan hukum yang diatur dalam peraturan perundang-undangan. Misalnya, penemuan hukum oleh hakim Mahkamah Agung dalam putusan perkara hukum kewarisan Islam di Indonesia, yaitu berkaitan dengan putusan hakim Mahkamah Agung tentang pewaris yang hanya meninggalkan satu anak perempuan (ahli waris) yang menghijab saudara laki-laki kandung Pewaris. Anak perempuan Pewaris mendapatkan seluruh bagian harta warisan dari Pewaris. Padahal dalam KHI Pasal 176 dinyatakan: "anak perempuan jika hanya seorang ia mendapat separoh bagian".4 Putusan yang lain, yaitu seorang ahli waris non muslim mendapatkan harta bagian dari pewaris muslim sebanyak harta yang diterima oleh ahli waris muslim dalam posisi yang

4 Lihat Putusan Pengadilan Agama Mataram: No. 85/Pdt.G/92/V/PA.MTR, tanggal 5 Nopember 1992 M, bertepatan tanggal 10 Jumadil Awal 1413 H., Jo. Putusan Pengadilan Tinggi Agama Mataram: No. 19/Pdt.G/1993/PTA. MTR, tanggal 15 September 1993 M, bertepatan tanggal 28 Rabiul Awal 1414 H., Jo. Putusan Mahkamah Agung RI: No. 86 K/AG/194, tanggal 28 April 1995.

Yudisia, Vol. 9, No. 1, Jan-Jun 2018 
sama.5 Masih banyak putusan hakim Mahkamah Agung berkaitan dengan hukum kewarisan Islam, yang bersifat penemuan hukm, sementara keluar dari Perundang-undangan, meskipun KHI bukan bertaraf Undang-undang, tetapi dari segi teknis dan formil KHI dapat digolongan Statue Law, karena secara teknis KHI dikodifikasi dan secara formil dikukuhkan oleh Inpres No.1 Tahun 1991.

Sepanjang sejarah hukum Islam, bahwa pemikiran hukum waris Islam tidak pernah berhenti, walaupun ada yang beranggapan bahwa pintu ijtihad telah tertutup namun sesungguhnya pemikiran hukum Islam tetap dilakukan setidaknya oleh dua golongan penegak hukum Islam yaitu hakim dan mufti. Hakim melakukan pemikiran hukum Islam dengan jalan melaksanakan hukum melalui putusan pengadilan, sedangkan mufti melalui fatwa-fatwa hukum (Mudzhar,1993:1-2). Perubahan dan pembaharuan hukum waris Islam telah terjadi secara nyata dalam sejarah pemikiran hukum Islam, untuk menyebut contoh apa yang terjadi dalam perumusan hukum waris Islam di Indonesia dengan konsep ahli waris pengganti telah merubah dan memperbarui hukum waris Islam di Indonesia (Rofiq, 2001: 116).

Hakim sebagai penegak hukum mempunyai posisi sentral dalam penerapan hukum. Hakim tidak hanya dituntut agar dapat berlaku adil tetapi ia juga harus mampu menafsirkan Undangundang secara aktual sesuai dengan kebutuhan dan perkembangan yang terjadi di tengah-tengah kehidupan masyarakat pencari keadilan dengan tetap mempertimbangan aspek keadilan, kepastian hukum dan nilai kemanfaatan (Manan, 2008: 278-285). Hakim dalam memutuskan perkara tidak hannya menerapkan hukum yang ada dalam teks undang-undang, tetapi ia juga harus melakukan pembaharuan-pembaharuan hukum ketika dihadapkan pada masalah-masalah yang diajukan kepadanya dan belum diatur dalam Undang-undang ataupun telah ada aturan tetapi dipandang tidak relevan dengan keadaan dan kondisi yang ada (hakim

${ }^{5}$ Lihat Putusan Mahkamah Agung Nomor: 368 K/AG/1995 tanggal 16 Juli 1998 dan Nomor: 51 K/AG/1999 tanggal 29 September 1999. 
menciptakan hukum baru atau jadge made law) (Manan, 2007: 913).

Hakim di lingkungan Mahkamah Agung di Indonesia sebagai salah satu penegak hukum Islam ternyata juga telah melaksanakan fungsi menetapkan putusan terhadap perkara-perkara yang diajukan kepadanya dengan terlebih dahulu mengemukakan pertimbanganpertimbangan hukum pada putusannya. Melalui putusan tersebut tidak dapat disangkal bahwa ia telah turut berperan dalam pemikiran hukum Islam terlebih lagi ketika putusannya mengandung pembaharuan terhadap pemikiran hukum Islam (Manan, 2007: 311-327).

Sehubungan dengan itu, perlu ditelaah mengenai berbagai aspek perkembangan eksistensi hukum kewarisan Islam di masyarakat oleh hakim Mahkamah Agung di Indonesia. Maka penulis tertarik, untuk meneliti penemuan hukum oleh hakim Mahkamah Agung dalam putasn perkara hukum kewarisan Islam di Indonesia, yang dibatasi pada tahun 1995 setelah lahirnya KHI sampai tahun 2015, karena kebanyakan dalam kasus putusan dari Peradilan Agama banding ke Pengadilan Tinggi sampai kasaski ke Mahkamah Agung rata-rata dapat putus dengan kisaran waktu dua tahun sampai tiga tahun. Dengan demikian, penulis tidak mengambil hasil putusan Mahkamah Agung dalam perkara kewarisan Islam tahun 2015, 2016 dan 2017.

\section{A. Pembahasan}

Studi terhadap hukum kewarisan Islam di Indonesia banyak mendapat perhatian para penulis sebelumnya. Meskipun sudah banyak kajian yang telah dilakukan, namun yang terkait langsung dengan kajian ini masih sangat terbatas. Sebagai gambaran keseriusan para peneliti sebelumnya dan sekaligus untuk memperlihatkan perbedaan dan persamaan dengan studi yang dilakukan ini, maka berikut ini diuraikakan hasil penellitian para sarjana berkaitan dengan hukum kewarisan Islam di Indonesia, sebagai berikut.

Kajian yang memiliki titik singgung dengan penelitian ini, adalah:

Pertama, Umar Syihab, Hukum Kewarisan Islam dan Pelaksanaannya di Wajo, disertasi pada Program Pascasarjana 
IAIN Sultan Alaudin Makasar, 1996. Penulisan ini menggunakan pendekatan teologis, sosiologis dan normatif. Penulisan ini juga menyimpulkan bahwa penerimaan syara' oleh sistem Hukum Adat Bugis Wajo "Pangadereng" telah melahirkan pelaksanaan hukum kewarisan Islam di Wajo.

Kedua, Aliyasa Abu Bakar, Ahli Waris Sepertalian Darah: Kajian Perbandingan Terhadapa Penalaran Hazairin dan Penalaran Fiqh Mazhab, desertasi pada Program Passcasarjana IAIN Syarif Hidayatullah Jakarta, 1996. Disertasi ini, disimpulan bahwa ijtihad Hazairin telah menciptakan sebuah sistem yang lebih padu dan menyeluruh, yakni melalui pendekatan antropologi telah memmbuka peluang menafsirkan ayat-ayat kewarisan dalam kerangka yang lebih luas.

Ketiga, Amir Syarifuddin, Pelaksanaan Hukum Kewarisan Islam dalam Lingkungan Adat Minangkabau. Disertasi Program Pascasarjana IAIN Syarif Hidayatullah Jakarta tahun 2002. Pendekatan yand dipakai adalah hukum yang berlaku dalam masyarakat (hukum agama yang dianutnya) Sedangakan hasil dalam penelitian ini adalah pelaksanaan hukum waris Islam dalam masyarakat Minangkabau sangat kental dengan nuansa kekeluargaan dan kekerabatan. Namun kekhususannya terletak pada corak garis keturunan ibu (matrilineal) dalam praktek pembagian harta warisan.

Keempat, Amir bin Mu'alim, Yurisprudensi Peradilan Agama. Disertasi Program Pascasarjana IAIN Sunan Kalijaga Yogyakarta tahun 2003. Pendekatan yang dipakai dalam penelitian ini adalah sejarah hukum, sosiologi dan antropologi. Sedangkan hasil penelitiannya, yaitu ada dinamika hakim yang mengedepankan alQuran dan sunnah baru kemudian perundang-undangan, namun yang sering dipakai adalah KHI.

Kelima, Edi Riadi, Dinamika Putusan Mahkamah Agung RI dalam Bidang Perdata Islam (Studi Tentang Pergeseran Hukum Perkawinan dan Kewarisan Islam Tahun 1991-2007). Disertasi Sekolah Pascasarjana (S3) UIN Syarif Hidayatullah Jakarta, tahun 2011. Penelitian ini, menggunakan teori responsif Philippe Nonet dan Philip Selzinck dan teori progresif Satjipto Rahardjo. Sedangkan pendekatan yang dipakai adalah pendekatan normatifkomparatif dan sosiologis. Sedangkan hasil penelitian dalam disertasi ini, yaitu dikatakan bahwa penafsiran kontekstual terhadap 
teks hukum lebih memenuhi rasa keadilan ketimbang penafsiran tekstual.

Keenam, tulisannya Akhmad Khisni dalam jurnal hukum no. edisi khusus vol. 18 oktober 2011 Fakultas Hukum Universitas Islam Sultan Agung (Unissula) Semarang, dengan judul "Ijtihad hakim peradilan agama bidang hukum kewarisan dan kontribusinya terhadap hukum nasional".. Metode penelitian dengan menggunakan pendekatan normatif dan paradigma konstruktivisme, dengan objek penelitian berupa yurisprudensi Mahkamah Agung dan putusan tersebut sebagai sumber primer dengan analisis data kualitatif. Hasil penelitian ini, dikatakan bahwa putusan hakim Mahkamah Agung yang keluar dari Undangundang merupakan hasil Ijtihad dalam upaya menangkap ruh atau maqașid al-syari'ah untuk menegakkan keadilan.

Daftar hasil penelitian tersebut di atas, tentu masih dapat diperpanjang lagi bahkan masih banyak yang belum tercantum, yaitu tulisan dalam bentuk artikel, makalah, atau refleksi mengenai topik ini. Namun demikian, daftar tersebut sudah dapat menggambarkan ruang yang belum mendapat perhatian penelitian sebelumnya adalah studi tentang hasil penemuan hukum hakim Mahkamah Agung berkaitan dengan putusan perkara hukum keluarga Islam di Indonesia.

\section{Penemuan Hukum Oleh Hakim Mahkamah Agung dalam Putusan Perkara Kewarisan Islam yang Mempersentasikan Pola-pola Pembaharuan Hukum Islam di Indonesia}

Putusan hukum kewarisan Islam oleh hakim Mahkamah Agung mulahi tahun 1995 sampai tahun 2014 terdapat banyak penemuhan hukum. Dalam hal ini dapat diketegorikan menjadi 6 (enam) bagian, yaitu; (1) putusan perkara kewarisan Islam di Indonesia yang diputus oleh hakim Pengadilan Agama dan Pengadilan Tinggi Agama yang dibatalkan oleh hakim Mahkamah Agung, (2) putusan perkara kewarisan Islam yang diputus oleh hakim Pengadilan Agama dan Pengadilan Tinggi Agama yang ditolak oleh hakim Mahkamah Agung, (3) putusan perkara kewarisan Islam yang diputus oleh hakim Pengadilan Agama dan Pengadilan Tinggi Agama yang ditolak dengan perbaikan oleh hakim Mahkamah Agung, (4) putusan perkara kewarisan Islam yang diputus oleh hakim Pengadilan Agama dan Pengadilan Tinggi Agama yang dinyatakan tidak dapat diterima oleh hakim 
Mahkamah Agung (5) putusan perkara kewarisan Islam yang diputus oleh hakim Pengadilan Agama dan Pengadilan Tinggi Agama yang dicabut oleh hakim Mahkamah Agung, dan (6) putusan perkara kewarisan Islam yang diputus oleh hakim Pengadilan Agama dan Pengadilan Tinggi Agama yang digugurkan oleh hakim Mahkamah Agung.

Dari 6 (enam) putusan hakim Mahkamah Agung berkaitan dengan perkara kewarisan Islam di Indonesia tersebut, yang akan menjadi obyek kajian dalam kajian ini, adalah putusan nomer 1, 2 dan 3, karena terkandung pemikiran atau ijtihad hakim Mahkamah Agung. Sedangkan putusan kewarisan Islam oleh hakim Mahkamah Agung di Indonesia kategori nomer 4, 5 dan 6 tidak menjadi obyek kajian ini, hanya menjadi perbandingan, karena didalamnya tidak mengandung pemikiran atau penemuhan hukum oleh hakim Mahkamah Agung, hanya berupa prosedur beracara yang diatur dalam Undang-Undang.

Penemuan hukum, menurut Sudikno Mertokusumo, lazimnya diartikan sebagai proses pembentukan hukum oleh hakim atau petugas-petugas hukum lainnya yang diberi tugas melaksanakan hukum terhadap peristiwa-peristiwa hukum konkret, atau merupakan konkretisasi dan individualisasi peraturan hukum (das sollen) yang bersifat umum dengan mengingat peristiwa konkret (das sein) tertentu (1993:4).

Menurut Utrecht bahwa penemuan hukum adalah berkaitan dengan peraturan perundang-undangan yang belum jelas atau permasalahan yang belum ada aturannya, dalam hal ini, hakim harus bertindak berdasarkan inisiatifnya sendiri untuk menyelesaikan perkara tersebut (Utrecht, 1983 :248). Sedangkan menurut Paul Scholtren yang dikutip oleh Achmad Ali, menyatakan bahwa penemuan hukum adalah penerapan peraturan pada peristiwa, karena peraturan harus ditemukan, baik dengan jalan interpretasi maupun dengan jalan analogi ataupun rechterjning (penghalusan atau pengkonkretan hukum) (1993:146).

Hakim mempunyai kedudukan yang penting dalam suatu sistem hukum, begitu pula dalam sistem hukum di Indonesia, karena hakim melakukan fungsi yang pada hakikatnya melengkapi ketentuan-ketentuan hukum tertulis melalui penemuan hukum (rechtvinding) yang mengarah kepada penciptaan hukum baru 
(creation of new law). Fungsi menemukan hukum tersebut harus diartikan mengisi kekosongan hukum (recht vacuum) dan mencegah tidak ditanganinya suatu perkara dengan alasan hukum (tertulis) tidak jelas atau tidak ada (Mochtar, 2002 :99).

Pada intinya, penemuan hukum yang dilakukan oleh hakim berawal dari peristiwa hukum konkret yang dihadapkan kepada hakim untuk diputuskan, karena putusan hakim harus memenuhi dimensi keadilan, kepastian hukum, dan juga kemanfaatan. Sangat sulit untuk mewujudkan ketiganya dalam suatu putusan, sehingga kadangkala putusan hakim dikatakan sebagai putusan yang tidak adil atau tidak mendengarkan rasa keadilan masyarakat. Putusan demikian itu, yang menimbulkan kontroversi serta polemik di kalangan masyarakat luas maupun kalangan hukum.

Penemuan hukum oleh hakim dilakukan dalam rangka tugas dan kewenangan dari hakim dalam memeriksa dan memutus suatu perkara yang dihadapkan kepadanya. Penemuan hukum oleh hakim dianggap yang mempunyai wibawa. Hasil penemuan hukum oleh hakim merupakan hukum yang mempunyai kekuatan mengikat sebagai hukum karena dituangkan dalam bentuk putusan (Mertokusumo \& Pitlo, 1993:5).

Dalam kaitan dengan tugas hakim dalam melakukan penemuan hukum, seorang hakim kadangkala dihadapkan pada suatu permasalahan mengenai peraturan perundang-undangan. Untuk itu, ada beberapa teori atau metode yang dapat digunakan oleh hakim dalam menghadapi permasalahan dimaksud, yaitu sebagai berikut:

1) Jika dalam isi suatu peraturan perundang-undangan mengandung suatu kekaburan norma (vage normen) atau terjadi makna ganda atau adanya konflik norma (antinomi normen), maka hakim dapat melakukan penafsiran atau interpretasi. Jadi, dalam hal ini peraturannya sudah ada, tetapi tidak jelas untuk diterapkan dalam peristiwa konkret, maka interpretasi teks terhadap peraturannya masih tetap berpegang pada bunyi teks tersebut.

2) Jika dalam suatu perkara yang variatif sifatnya, belum ada peraturan perundang-undangan yang mengaturnya, maka hakim dapat melakukan konstruksi. Dalam hal ini 
peraturannya belum ada, sehingga terdapat kekosongan hukum (rechts vacuum) atau lebih tepat disebut dengan kekosongan undang-undang (wet vacuum) (Hamidi, 1999 :52-53).

\section{Penemuan Hukum Oleh Hakim Mahkamah Agung dalam Putusan Perkara Kewarisan Islam dilihat dari Aspek Istinbat Al-hukm}

Putusan hukum kewarisan Islam oleh hakim Mahkamah Agung mulahi tahun 1995 sampai tahun 2014 dilihat dari aspek istinbat al-hukm terdapat perubahan hukum. Perubahan hukum dalam suatu negara dapat mempengaruhi perubahan sosial di masyarakat. Demikian pula sebaliknya, perubahan sosial di masyarakat dapat membawa kepada perubahan hukum dalam suatu negara. Berkenaan dengan hal tersebut, maka dalam disertasi ini juga akan menggunakan teori perubahan hukum yang dikemukakan oleh Ibnu Qayyim al-Jauziyyah; "aplikasi prinsip-prinsip dan asasasas hukum Islam di masyarakat hendaknya koheren dengan perubahan hukum Islam sesuai dengan situasi dan kondisi dalam masyarakat muslim itu sendiri" (al-Jauziyyah, 1980:3). Logika semacam ini, sesuai dengan kaidah fiqhiyah yang berbunyi:

$$
\text { تغير الأحكام بتغير الأزمنة والأمكان والأحوال }
$$

Artinya: "Perubahan hukum dapat terjadi karena perubahan era, area, dan suasana" (Uśman,1997:145).

Dalam kaidah lain dikatakan bahwa :

$$
\text { الحكم يدور مع علته وجودا و عداما }
$$

Artinya: "Hukum itu bergerak mengikuti illatnya (kemaslahatannya), ada illat ada hukum, tidak ada illat tidak ada hukum" (Asmuni,1976:71).

Selain itu, dalam mempertajam permasalahan tersebut, penulis juga menggunakan teori pragmatisme legal realism dari Roscoe Pound, mengajarkan bahwa "law as a tool of social engineering”, (1972:71) hukum berfungsi sebagai sarana untuk merekayasa masyarakat ke arah tertentu yang diinginkan 
(Darmodiharjo dan Sidharta, 2002:128). Teori ini didasarkan atas keyakinan bahwa : (1) antara hukum dan masyarakat terdapat hubungan yang fungsional, (2) hukum yang merupakan sistem pengaturan yang terkendali dan memaksa (coersif) berfungsi menciptakan keseimbangan antara berbagai kepentingan, (3) hukum merupakan pemikiran yang sistematis, mudah disempurnakan setiap kali untuk memenuhi fungsinya sebagai sarana social engineering, dan (4) kehidupan sosial dapat dipengaruhi oleh hukum dengan mudah, manakala kepentingan mereka terjamin (Simanjuntak, dan Markus, 2010:161-162).

Menurut Roscoe Pound, dalam rangka memfungsikan hukum sebagai sarana social engineering, maka haruslah diciptakan hukum yang : (1) dapat menciptakan keseimbangan antara berbagai kepentingan; (2) mengarahkan kehidupan sosial ke arah yang lebih baik; (3) menciptakan keadaan masyarakat yang tertib untuk mencapai cita-cita yang diinginkan; dan (4) mampu mendorong terjadinya perubahan sosial dan dapat memaksa masyarakat untuk mengikuti norma-norma baru yang ditetapkan. Menurutnya, hukum tidak lagi dilihat hanya sekedar tatanan penjaga status quo, tetapi sebagai sebuah sistem pengaturan untuk mencapai tujuan-tujuan tertentu secara terencana (2010:161-162).

Teori ini kemudian dikembangkan oleh Mochtar Kusumaatmadja sebagai teori hukum pembangunan (Manan,2005:21). Menurut Kusumaatmadja, hukum yang baik harus memenuhi empat syarat, yaitu pertama, sesuai dan memperhatikan kesadaran hukum masyarakat; kedua, tidak boleh menghambat modernisasi; ketiga, dapat menjadi sarana pembaharuan masyarakat; dan keempat, mempunyai kekuatan legalisasi dari negara. Mochtar mengemukakan bahwa "hukum tanpa kekuasaan adalah angan-angan dan kekuasaan tanpa hukum adalah kezaliman" (1976:11).

Di samping itu, dalam hukum Islam dikenal dengan teori nas hukum yang tetap (sabat) dan yang bisa berubah (mutaghayyirat). Aspek-aspek yang tetap ( $\dot{s} a b a t)$ menjadi sandaran hukum Islam. Maka, tidak boleh ada upaya pengebirian terhadap berbagai ketetapan tersebut. Dalam syariat Islam juga terdapat berbagai kaidah yang mengandung unsur-unsur dinamis yang memungkinkan syariat tersebut tetap berlaku di setiap zaman. 
Menurut Abdul Halim Usays bahwa di antara spesifikasi yang paling menonjol dalam hukum Islam adalah wataknya yang

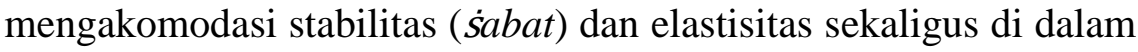
keteraturan dan keseimbangan yang tidak ada bandingannya. Oleh karena itu, hukum Islam tidak cenderung dikatakan tetap secara mutlak yang membuat kehidupan dan aspek kemanusiaan menjadi jumud (stagnan). Sebaliknya, ia juga tidak dikatakan ketidakpastian serta ketidak abadian nilai-nilai dan prinsip-prinsipnya. Akan tetapi, hukum Islam senantiasa berada di tengah-tengah di antara keduanya (1998:121).

Menurut al-Qardhawi hukum Islam mengandung aspek perubahan (mutaghayyir) atau al-murunah (elastisitas). Hal ini, disebabkan beberapa faktor, yaitu sebagai berikut :

a) Allah sebagai pembuat hukum tidak menetapkan secara taken for granted segenap hal, bahkan Dia membiarkan adanya suatu wilayah yang luas tanpa terikat dengan naș. Tujuannya adalah untuk memberikan keleluasaan, kemudahan, dan rahmat bagi makhluk-Nya.

b) Sebagian besar naș datang dengan prinsip-prinsip yang umum dan hukum-hukum universal yang tidak mengemukakan berbagai perincian dan bagian-bagiannya, kecuali dalam perkara yang tidak berubah karena perubahan tempat dan waktu seperti dalam perkara-perkara ibadah.

c) Naș-naș yang berkaitan dengan hukum-hukum yang parsial menghadirkan suatu bentuk mukjizat yang mampu memperluas berbagai pemahaman dan penafsiran, baik secara ketat maupun secara longgar, baik dengan menggunakan harfiah teks maupun yang memanfaatkan substansi dan maknanya. Jarang sekali ditemukan teks-teks yang tidak menyebabkan variasi makna-maknanya dan penggalian hukum-hukum dari teks-teks tersebut.

d) Dalam pemanfaatan wilayah-wilayah terbuka untuk penetapan atau penghapusan hukum Islam terdapat kemungkinan untuk memanfaatkan berbagai sarana yang beraneka ragam, yang menyebabkan para mujtahid berbeda pendapat dalam penerimaan dan penentuan batas penggunannya. Di sinilah kemudian muncul peranan qiyas, 
istihsan, istihlah, al-urf, istișhab, dan lain-lain, sebagai dalildalil bagi semua yang tidak ditemukan naṣnya.

e) Adanya prinsip pengantisipasian berbagai keadaan darurat, berbagai kendala, serta berbagai kondisi yang dikecualikan dengan cara menggugurkan hukum atau meringankannya. Hal ini dimaksudkan untuk memudahkan dan membantu manusia karena kelemahan mereka di hadapan berbagai keadaan darurat memaksa serta kondisi-kondisi yang menekan. "Ad-darurat tubihu al-maḩurat (berbagai kondisi darurat menyebabkan bolehnya hal-hal yang terlarang)" (t.th:321).

\section{Tingkat Progresifitas Penemuan Hukum Oleh Hakim Mahkamah Agung dalam Putusan Perkaraa Kewarisan Islam Terhadap Isu Keadilan di Indonesia.}

Putusan hukum kewarisan Islam oleh hakim Mahkamah Agung mulahi tahun 1995 sampai tahun 2014 tingkat progresifitasnya sangat tinggi dalam merespon keadilan dalam kehidupan di masyarakat, berdasarkan pertimbangan kemaslahatan. Dalam teori al-Mașlahah ${ }^{6}$ dari al-Syatibi dalam bukunya alMuwafaqat. Menurut al-Syatibi (w. 790 H), maksud atau tujuan Allah dan Rasul-Nya dalam menetapkan hukum Islam, dapat diketahui bukan dari satu dalil, melainkan dari sejumlah dalil yang dihimpun dan diteliti secara induktif. Dari penelitian para ulama terhadap sejumlah ayat al-Qur'an dan al-hadis yang dijadikan landasan hukum, diketahui bahwa tujuan Allah dalam mensyariatkan suatu hukum adalah untuk mewujudkan kemaslahatan bagi manusia di dunia dan di akhirat. Kemaslahatan yang diwujudkan itu menurut al-Syatibi, dan sebelumnya menurut al-Ghazali (w. $505 \mathrm{H}$ ), terbagi kepada tiga tingkatan, yaitu : daruriyat sebagai kemaslahatan primer, hajiyat sebagai kemaslahatan sekunder, dan tahșiniyat sebagai kemaslahatan tertier. Kemaslahatan daruriyat meliputi lima aspek kemanusiaan, yaitu melindungi keselamatan jiwa, agama, akal, keturunan, dan

${ }^{6}$ Teori Mașlahah ini diperkenalkan oleh Imam Al Syathibi, al Mawardi, al Ghazali, Najamuddin al Thufi, Ibnu Taimiyah, al Thabathaba'I, Mustafa Zaid, dan Abdul Wahab Khallaf. 
harta kekayaan manusia yang dikategorikan dengan al maqașid al khamsah (T.th :2-4).

Mașlaḥah sebagai tujuan syariah harus menjadi kebijakan pemegang kekuasaan, baik legislatif, eksekutif, maupun yudikatif. Kaidah hukum Islam memberikan suatu pedoman bahwa:

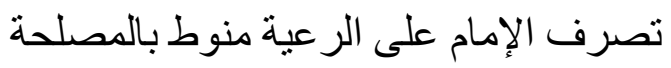

Artinya : "kebijakan imam (penguasa) terhadap rakyatnya harus didasarkan pada kemaslahatan umat" (Zaidan, 2008 : 153).

Al-Syatibi berpendapat, bahwa teori mașlahah dapat diterapkan apabila dipenuhi empat syarat, yaitu : (1) keadaanya sudah mencapai tingkat daruriyat di mana kemaslahatannya sangat esensial dan primer; (2) kemaslahatannya bersifat qath'iyyah, yakni sangat jelas dan tegas; (3) kemaslahatan tersebut bersifat kuliyah (universal); dan (4) kemaslahatan tersebut berdasarkan dalil-dalil (alasan-alasan) yang mu'tabarah (dalil universal) dari keseluruhan qarinah) (t.th: 11).

Berangkat dari uraian tersebut, dapat dipaparkan pendapat Mahmoud Syaltout, bahwa syariah adalah tatanan yang ditetapkan Allah atau yang ditetapkan pokok-pokoknya saja (Syaltout,1996:12). Pendapat tersebut dapat disimpulkan, syariah dalam kategori "tatanan yang ditetapkan Allah", adalah bersifat absolut, universal, dan muabbadah sehingga tidak mungkin ada perubahan. Sedangkan syariah dalam kategori "yang ditetapkan pokok-pokoknya saja", adalah bersifat relatif, lokal, dan temporer sehingga dimungkinkan terjadinya perubahan dengan mengikuti kemaslahatan manusia.

Dalam ilmu ușul al-fiqh, mașlaḥah dibagi menjadi tiga yaitu, (1) maslahah mașlaḥah mu'atabarah, yaitu mașlaḥah yang alasan ('illat)-nya telah ditunjukkan oleh syara' baik secara langsung maupun tidak langsung, (2) mașlaḥah mursalah atau al-istishlah, yaitu mashlahah yang tidak dilarang oleh syara' tetapi juga tidak diperintahkan atau dapat diartikan sesuatu yang dianggap bermanfaat (maslahat). Namun, tidak ada ketegasan hukum dan pembuat syara' untuk menolaknya. Menurut pengertian bahasa, "mașlaḥah" berarti manfaat, sedangkan "mursalah" berarti lepas. Jadi, mașlaḥah mursalah adalah mașlạ̣ah (manfaat) yang terlepas 
dari dalil khusus; dan (3) mașlaḥah mulghah, yaitu mashlahah yang meskipun alasannya dianggap baik oleh akal tetapi karena bertentangan dengan ketentuan syara' sehingga harus ditinggalkan (Syarifuddin, 2001: 329-332).

Berdasarkan uraian tersebut dapat disimpulkan, bahwa teori mașlahah mengajarkan; pertama, bahwa hukum itu dibuat untuk kemaslahatan manusia, yaitu melindungi agama, jiwa, akal, keturunan, dan harta kekayaan manusia, agar mendapat manfaat dan terhindar dari kerusakan. Kedua, apabila dalam mewujudkan ke-mașlaha-tan itu menghendaki perubahan hukum, maka hukum pun harus diubah mengikuti kemaslahatannya, meskipun harus keluar atau berbeda dengan teks hukumnya. Ketiga, untuk mewujudkan kemaslahatan harus dibentuk hukum baru, mesikupun tidak ada perintah dalam syariah. Keempat, apabila terjadi pertentangan atau perbedaan kemaslahatan satu sama lain, maka diambil mașlaḥah yang lebih besar atau kemaslahatan yang paling unggul (kuat), sesuai tujuan syariah, sehingga kemaslahatan hajiyat sebagai ke- mașlaḥah-tan sekunder, dan kemaslahatan hajiyat harus didahulukan atas ke-mașlaḥah-tan tașiniyat sebagai kemaslahatan tertier. Kelima, pembentukan hukum baru melalui mașlahah berdasarkan akal manusia (mursalah) tidak boleh bertentangan dengan ketentuan naș (syariah) yang bersifat 'ubudiyah yang menjadi hak Allah.

Dengan demikian, teori mașlaḥah ini harus diterapkan secara proposional. Dalam hal-hal yang berkaitan dengan hukum wad'i $i$ (yakni, hukum yang berfungsi melindungi hak-hak Tuhan, hak-hak publik, ketertiban umum, kepastian hukum, dan nilai-nilai kebenaran), maka kepastian hukum harus diutamakan. Dalam halhal yang berkaitan dengan hukum taklifi (yakni, hukum yang mengatur hak dan kewajiban antar subjek hukum / mukallaf), rasa keadilan juga harus diutamakan. Jika terjadi kontradiksi (perbenturan) antara kepastian hukum dan rasa keadilan, maka diterapkan teori mașlaḥah, yakni manfaat yang lebih luas. Demikian pula jika terjadi pertentangan kemaslahatan satu sama lain, maka diambil mașlaḥah yang lebih besar, sesuai tujuan syariah. Sebagai mana kaidah hukum Islam sebagai berikut:

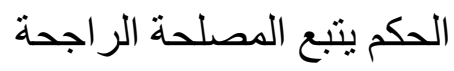

Yudisia, Vol. 9, No. 1, Jan-Jun 2018 


\section{Shobirin}

Artinya : "Hukum itu mengikuti kemaslahatan yang paling unggul (kuat)" (Asmuni, 1976:71).

\section{B. Simpulan}

Dari uraian tersebut di atas, dapat disimpulkan bahwa kerangka konseptual dalam kajian permasalahan tersebut, terdiri atas enam komponen, yaitu: (1) sumber hukum tertulis dalam peraturan perundang-undangan; (2) sumber hukum tidak tertulis, antara lain al-Quran, hadis dan kitab fiqh; (3) hukum tertulis, yakni kaidah hukum dalam pasal-pasal dari perundang-undangan baik KHI maupun Hukum Perdata; (4) hukum tidak tertulis, yakni doktrin ahli hukum dan pendapat fuqaha tentang kewarisan Islam; (5) pemeriksaan perkara kewarisan Islam, sesuai dengan prosedur peradilan; (6) putusan hakim Mahkamah Agung dalam perkara kewarisan Islam di Indonesia, yang berupa naskah

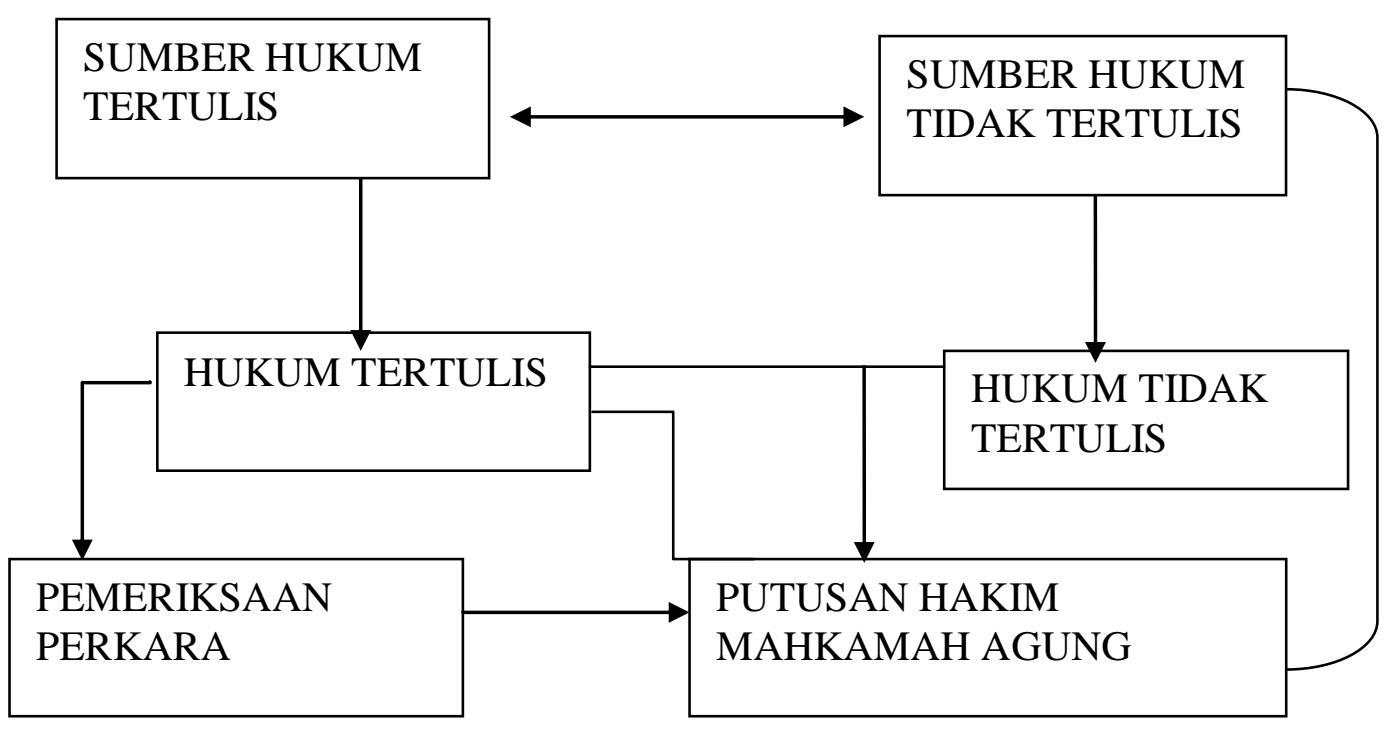

Keterangan:

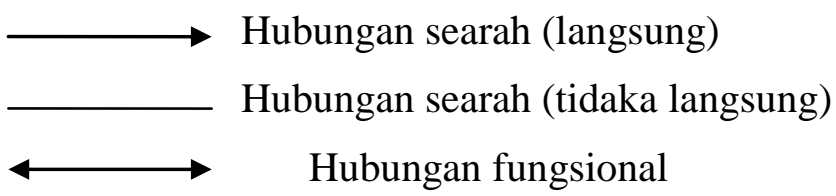


Dapat diuraikan sebagai berikut: Pertama, dalam putusan hakim Mahkamah Agung berkaitan dengan perkara kewarisan Islam di Indonesia memiliki dimensi ganda, yaitu putusan itu merupakan wujud penerapan hukum dalam peristiwa hukum yang konkret, yakni perkara (legal case) berkaitan dengan hukum kewarisan Islam di Indinesia. Di sisi lain, putusan tersebut juga mencerminkan pembentukan atau penemuan hukum (rechtsfinding) oleh hakim Mahkamah Agung. Kedua, putusan hakim Mahkamah Agung dalam perkara hukum kewarisan Islam di Indonesia didasarkan pada hukum tertulis, baik hukum material (substantif) maupun hukum formal (prosedural). Hukum tertulis itu bersumber pada peraturan perundang-undangan yang berlaku. Ketiga, putusan hakim Mahkamah Agung dalam perkara kewarisan Islam di Indonesia juga didasarkan pada hukum tidak tertulis, terutama doktrin para ahli hukum dan pendapat fuqaha. Di samping itu, dalam berbagai hal, didasarkan pada prilaku manusia yang mempola, ajeg dan mengikat ( $a l$ - 'adah). Hal itu merupakan bagian dari tatanan hukum nasional yang bersifat majemuk. Keempat, dalam proses pengambilan keputusan perkara hukum kewarisan Islam di Indonesia, hakim Mahkamah Agung sebagai penegak hukum dan keadilan wajib menggali, mengikuti dan memahami nilai-nilai hukum yang hidup dalam masyarakat. Hal itu, memberi peluang kepada hakim Mahkamah Agung untuk melakukan penemuan hukum baru. Kelima, putusan hakim Mahkamah Agung dalam perkara kewarisan Islam di Indonesia, dilakukan terhadap perkara yang diajukan banding ke Mahkamah Agunga setelah diputus di Pengadilan Tinggi. Keenam, putusan hakim Mahkamah Agung yang telah memperoleh kekuatan hukum tetap (rechtskracht) menjadi yurisprudensi, apabila dijadikan pedoman dalam pengambilan keputusan pengadilan tentang perkara yang sama. Yurisprudensi itu menjadi sumber hukum tertulis, meskipun sistem peradilan di Indonesia tidak menganut asa preseden. 


\section{DAFTAR PUSTAKA}

Al-Syatibi, Abi Ishaq, t.th, al-Muwafaqat fi Usul as-Syari'ah, Beirut Libanon: Dar al-Ma'arif.

Al-Syaukani, M., Ibn Ali, 1973, Irsyad al-Fuhul ila Tahqiq alHaqq min Ilm al-Ushul, Kairo : Mushthafa al-Babi al-Halabi wa-Awladuhu.

Al-Syayrazi, Abu Ishaq, Ibrahim, t.th , al-Luma' fi-Ushul al-Fiqh, Surabaya : Syirkah Maktabah wa-Mathba'ah Ahmad Ibn Sa'ad ibn Nabhan wa-Awladuh.

Al-Jauziyah, Ibnu Qayyim, 1980, I'lam al-Muwaqqi'in, Kairo: Maktabah al-Kulliyyat al-Azhariyyah

Al-Qardawi, Yusuf, t.th, Al-Siayasah Al-Syar'iyyah Fi ־aui Nușus Al-Syari'ah wa Maqașidiha, Kairo : Maktabah Wahbah.

Asmuni A.R., 1976, Qaidah-Qaidah Fiqh, Jakarta: Bulan Bintang

Darmodiharjo, Darji dan Sidharta, 2002, Pokok-pokok Filsafat Hukum, Apa dan Bagaimaan Filsafat Hukum Indonesia, Jakarta: Gramedia Pustaka Utama.

Hamidi, Jazimi, 1999, Penerapan Azaz-azaz Umum Penyelenggaraan Pemerintah yang Layak (AAUPPL) di Lingkungan Peradilan Admistrasi Indonesia, Bandung : Citra Aditya Bakti.

Kusumaatmaja, Mochtar, 2002, Konsep-Konsep Hukum dalam Pembangunan, Bandung: Alumni. Kusumaatmadja, Mochtar, 1976, Fungsi dan Perkembangan Hukum Dalam Pembangunan Nasional, Bandung: Bina Cipta.

Mertokusumo, Sudikno, 1998, Hukum Acara Perdata Indonesia, Yogyakarta: Liberty.

Yogyakarta: 2007, Penemuan Hukum Sebuah Pengantar, , dan Pitlo,.A, 1993, Bab-Bab Tentang Penemuan Hukum, Bandung: Citra Aditya Bakti.

Manan, Bagir, 2000, Wajah Hukum di Era Reformasi, Bandung: Citra Aditya Bakti.

, 2007, Hakim sebagai Pembaharu Hukum dalam Varia Peradilan Majalah Hukum, Tahun Ke XXII No. 254 Januari 2007, Jakarta: Ikatan Hakim Indonesia.

Machmudin, Dudu Duswara, 2006, Peranan Keyakinan Hakim dalam Memutus Suatu Perkara di Pengadilan, Majalah 
Hukum Varia Peradilan Edisi No. 251 Bulan Oktober 2006, Jakarta: Ikahi.

Mulyadi, Lili, 2006, Pergeseran Perspektif dan Praktik dari Mahkamah Agung Mengenai Putusan Pemidanaan, Majalah Hukum Varia Peradilan Edisi No. 246 Bulan Mei 2006, Jakarta: Ikahi.

Manan, Abdul, 2005, Aspek-aspek Pengubah Hukum, Jakarta:

Kencana Prenada Media.

, 2007, Reformasi Hukum Islam Di Indonesia

Tinjauan dari Aspek Metodologis, Legalisasi, dan Yurisprudensi, Jakarta: PT Raja Grafindo Persada. 2008, Penerapan Hukum Acara Perdata Di

Lingkungan Peradilan Agama, Jakarta: Prenada Media Grup.

Mudzhar, Atho, M. 1993, Fatwa-Fatwa Majelis Ulama Indonesia

Sebuah Studi tentang Pemikiran Hukum Islam di Indonesia 1975-1988, Jakarta : INIS.

Rasjidi, Lili., M, dan Thania Rasjidi, Ira, 2004, Dasar-Dasar

Filsafat dan Teori Hukum, Bandung: Citra Aditya Bakti.

Rasyidi, Lili., M, dan Sidharta, Arif, 1997, Filsafat Hukum Madzhab dan Refleksinya, Bandung: Rosdakarya.

Ruslam, Rosadi, 2004, Metode Penelitian Public Relations dan Komunikasi, Jakarta, Raja Grafindo Persada

Rofiq, Ahmad, 2001, Pembaharuan Hukum Islam di Indonesia, Yogyakarta: Gama Media

Rahardjo, Satjipto, 1983, Hukum dan Perubahan Sosial, Bandung: Alumni

Soekanto, Soerjono dan Sri Mamudji, Sri, 2009, Penelitian Hukum Normatif

Suatu Tinjauan Singkat, Cetakan ke - 11, Jakarta : Raja Grafindo Persada.

Dirdjosisworo, Sudjono, 1983, Sosiologi Hukum Islam: Studii tentang Perubahan Hukum dan Sosial, Jakarta: Rajawali.

Suparmono, Rudi, 2006, Peran Serta Hakim dalam Pembelajaran Hukum, Majalah Hukum Varia Peradilan Edisi No. 246 Bulan Mei 2006, Jakarta: Ikahi.

Syalthout, Mahmud, 1996, Al Islamu Aqidah wa Syari'ah, Daarul Qalam.

Syarifuddin, Amir, 2001, Ilmu Ushul Fiqh, Jilid 2, Jakarta: Logos Wacana Ilmu.

Utrecht, 1983, Pengantar dalam Hukum Indonesia, Jakarta: Ichtiar.

Yudisia, Vol. 9, No. 1, Jan-Jun 2018 
Uṡman, Muslih, 1997, Kaidah-kaidah Ushuliyyah dan Fiqhiyyah Pedoman Dasar Dalam Istimbath Hukum Islam, Jakarta: Rajawali Press.

Uways, Abdul Halim, 1998, Fiqh Statis Dinamis, Terj. Zarkasi Humaidi, Bandung: Pustaka Hidayah

Pound, Roscoe, 1972, Pengantar Filsafat Hukum, Jakarta: Bhatara.

Zaidan, Abdul Karim, 2008, 100 Kaedah Fikih Dalam Kehidupan Sehari-hari, Terj. Muhyidin Mas Rida, LC, Jakarta: Pustaka al Kautsar.

Zahrah, M., Abu, 1958, Ushul al-Fiqh, Beirut : Dar al-Fikr alArabi. 